\title{
Cost effectiveness of routine postmortem histology
}

\author{
W A REID \\ From the Department of Pathology, University of Leeds
}

SUMMARY In a retrospective study of the records of 160 necropsies it was found that, according to the clinical and gross necropsy findings, no clinically important abnormality would have been anticipated in $46 \%$ of the tissue samples. The estimated annual cost of processing this material alone was $£ 10500$, including the salary of one full time medical laboratory scientific officer (MLSO). Few of the microscopic findings led to a change in diagnosis. It is suggested that unselected postmortem histology is, for diagnostic purposes, not cost effective.

Histology makes a useful contribution to the final diagnosis in many necropsy cases. It has, however, a price. In 1985 the estimated cost to our pathology department (Leeds General Infirmary) of processing 7843 blocks from 782 necropsies was $£ 19200$. This required at least 3850 person hours. Part of the work load is due to routine sampling of certain normal or almost normal tissues. This commonly recommended practice seems not to have been evaluated, even in the few publications on the cost effectiveness of the necropsy. ${ }^{1}$

The present retrospective study was undertaken to assess the diagnostic value of taking histological samples, when not indicated by the clinical and gross necropsy findings, and to estimate the cost of processing this material.

\section{Material and methods}

CRITERIA FOR HISTOLOGICAL SAMPLING

Before the study began it was decided that to establish a final diagnosis, postmortem histological study of the following was justifiably indicated:

(i) Any macroscopically abnormal tissue, other than those showing certain specific minor changes, listed below.

(ii) Any macroscopically normal tissue which the clinical or gross necropsy findings suggested might show

(a) a microscopic abnormality,

(b) part of a systemic disease or a syndrome of obscure aetiology.

Accepted for publication 9 October 1986
SELECTION OF TISSUES

In all other circumstances in which a tissue was grossly normal and the above criteria did not apply it was considered that there was no clear indication for taking histology. Those normal tissues under study included liver, kidney, spleen, heart, lung, prostate, pancreas, thyroid, adrenal and brain. Furthermore, tissues showing certain common minor abnormalities were also included - namely, lung (oedema), kidney (fine granularity), prostate (nodular enlargement), heart (old fibrosis), and liver, lung, or spleen (congestion). These conditions were selected because it seemed likely that histology would not radically change the final diagnosis.

The necropsy records from September 1 to December 311979 of the pathology department of The General Infirmary at Leeds were reviewed. Cases in which the documentation was incomplete were excluded.

From the clinical summary and gross necropsy findings the tissues which merited histological study were determined according to the above criteria and excluded from further consideration. Cases where indication $(b)$ applied were also not further considered as it was thought that microscopy of any tissue might be justified. Thus the study was confined to tissues which had been examined histologically with no apparent indication. In each case the histological findings stated in the necropsy report were recorded.

\section{COSTING}

The number of blocks of these tissues and the total sampled from each case were obtained from the work sheets. An estimate was made of the annual cost of materials, including consumables (solvents, chemicals, dyes, waxes, plastic and glass disposables, disposable knives, maintenance) and capital equipment. 
The labour time and cost for medical laboratory scientific officers (MLSOs) to process the tissues under study was calculated from the fraction of the total blocks processed by the department. The labour time and cost for pathologists was calculated from an estimate of the average daily time required to examine and report relatively straightforward sections. The extra secretarial time and cost were also estimated.

\section{Results}

In the four months under study 177 postmortem examinations were performed. Seventeen cases were excluded because of insufficient data. In a further 22 cases all the histology was regarded as indicated because there was a systemic disorder-namely, disseminated malignancy $(\mathrm{n}=12)$, diabetes mellitus $(n=4)$, shock $(n=3)$, gout $(n=1)$, systemic lupus

Table Histological findings in grossly normal or near normal postmortem tissues*

\begin{tabular}{|c|c|c|c|}
\hline Tissue & $\begin{array}{l}\text { Gross } \\
\text { appearance }\end{array}$ & No & Microscopic appearance \\
\hline Liver & Congested & 49 & $\begin{array}{l}\text { Normal } 28 \text {, congested } 12 \text {, fatty } 4 \text {, } \\
\text { other minor changes } 5 \\
\text { Congested } 24 \text {, normal } 6 \text {, fatty } 4 \text {, } \\
\text { portal inflammation } 2 \text {, ?shock } 1 \text {, } \\
\text { "toxic" } 1 \text {, haemosiderin } 1\end{array}$ \\
\hline Kidney & $\begin{array}{l}\text { Finely } \\
\text { granular }\end{array}$ & 49 & $\begin{array}{l}\text { Normal } 26, \text { nephrosclerosis } 15 \text {, } \\
\text { hypertensive } 5 \text {, other minor } \\
\text { changes } 4 \\
\text { Focal nephrosclerosis } 27 \text {, } \\
\text { hypertensive } 3 \text {, other minor } \\
\text { changes } 3\end{array}$ \\
\hline Spleen & Congested & 58 & $\begin{array}{l}\text { Normal } 45 \text {, congested } 6 \text {, sarcoid } \\
\text { granulomas } 1 \text {, other minor } \\
\text { changes } 6 \\
\text { Congested } 6 \text {, normal } 2\end{array}$ \\
\hline Heart & Scarred & 18 & $\begin{array}{l}\text { Normal } 17 \text {, scarring } 15 \text {, acute } \\
\text { myocardial infarction } 1, \text { focal } \\
\text { polymorphs } 1 \\
\text { Scarred } 16 \text {, acute myocardial } \\
\text { infarction } 1 \text {, normal } 1\end{array}$ \\
\hline Lung & $\begin{array}{l}\text { Normal } \\
\text { Oedema }\end{array}$ & $\begin{array}{r}5 \\
37\end{array}$ & $\begin{array}{l}\text { Normal } 2 \text {, granulomas } 2 \text {, oedema } 1 \\
\text { Oedema } 26 \text {, bronchopneumonia } 8 \text {, } \\
\text { congestion } 2 \text {, infarct and } \\
\text { thrombus } 1 \text {, interstitial fibrosis } 1 \\
\text { Congestion } 1 \text {, bronchopneumonia } 1\end{array}$ \\
\hline Pancreas & Normal & 49 & $\begin{array}{l}\text { Normal or autolysed } 45 \text {, atrophy } 2 \text {, } \\
\text { fibrosis } 2\end{array}$ \\
\hline Thyroid & Normal & 30 & $\begin{array}{l}\text { Normal } 27 \text {, nodular } 2 \text {, focal } \\
\text { thyroiditis } 1\end{array}$ \\
\hline Adrenal & Normal & 30 & Normal 29, lipid depletion 1 \\
\hline Prostate & $\begin{array}{l}\text { Benign } \\
\text { nodular } \\
\text { enlargement }\end{array}$ & 11 & $\begin{array}{l}\text { Normal } 4 \text {, benign nodular } \\
\text { hyperplasia } 5 \text {, carcinoma } 1 \text {, } \\
\text { calculi } 1\end{array}$ \\
\hline Brain & Normal & 24 & $\begin{array}{l}\text { Normal } 22 \text {, ring haemorrhages } 1 \text {, } \\
\text { arteriosclerotic changes } 1\end{array}$ \\
\hline
\end{tabular}

*Certain figures do not exactly add up, as some tissues showed more than one change. erythematosus $(n=1)$, or a disorder of obscure nature-namely unexplained neurological symptoms $(n=1)$. The table shows the findings in the tissues studied in the remaining 138 cases.

The total number of blocks sampled in the 160 cases studied was 2113 (average 13.2 per case), of which $976(46 \cdot 2 \%)$ were accounted for by the tissues analysed (table).

In 1979600 postmortem examinations were performed. Assuming that $46.2 \%$ of the histological samples taken were not indicated, the annual cost to the department (1986 costs) of processing the extra 3659 blocks is estimated as follows:

Materials

(a) Consumables

(b) Capital equipment

£ 2000

$£ 500$

Labour

(a) Medical laboratory scientific officer (full time)

(b) Registrar pathologist (30 minutes per day)

(c) Secretary (10 minutes per day) Total

$£ 7250$

$£ \quad 700$

$£ 50$

$£ 10500$

\section{Discussion}

The detection of nine cases of bronchopneumonia by examination of the lung in 44 cases might be considered sufficiently good return to justify routine microscopy of the lung. The two myocardial infarcts were also important findings, but their discovery required the study of 52 hearts. Selective use of other investigations, ${ }^{2}$ such as gross staining techniques, histochemistry, or potassium:sodium ratio determination might be more cost effective than routine cardiac histology.

Few of the other microscopic findings were important enough for the final necropsy diagnosis to be changed, yet the tissue examined was about half of the total necropsy tissue processed for histology by the pathology department.

Although an annual cost of $£ 10500$ is but a small proportion of the total cost of necropsies (around $£ 1000$ per case in 1985 , based on estimates by Yesner in $1978^{3}$ ), there are other disadvantages. Much of the work is carried out by MLSOs and is tedious. For the pathologists, the prospect of examining numerous rather uninteresting slides may well delay completion of the final necropsy report.

Tissue may, of course, be sampled for histological study for reasons other than to establish a final diagnosis. Firstly, junior pathologists must become acquainted with the spectrum of normality in necropsy tissues. It is not clear that this is best achieved by examination of large numbers of pieces of normal tissues for several years. A more specific

.


training schedule might be adequate-for example, with sampling in the first (say, 10-20) cases only, with close supervision. The criteria for histological examination listed above should still permit plenty of experience in examining tissues that subsequently prove to be normal. Perhaps study of a set of sections from tissues at different known stages of autolysis would also be helpful. Secondly, although certain tissues may be useful for future retrospective research, the value of large numbers of pieces of normal postmortem tissue for this purpose is doubtful. Thirdly, in selected medicolegal cases where an inquest is likely, it may be wise to retain blocks of tissue.

Despite these undoubtedly valid reasons for taking necropsy histology, there is room for considerable improvement in cost effectiveness. The possibility that occasional important findings might be missed does not justify limitless investigation in any branch of medicine. ${ }^{4}$ It would be interesting to know whether similar analysis of the necropsy records of other pathology departments yielded results like those in the present study. If so, a set of recommended guidelines such as those suggested above could be drawn up and the amount of tissue sampled for histological study drastically reduced without serious compromise of final diagnosis, research, or training of pathologists.

I thank Dr WD Thompson, pathology department, University of Aberdeen, and Professor CC Bird, Mr I Banks, Mr D Loney, Dr JN Bulmer, and Dr MF Dixon, pathology department, University of Leeds, for helpful comments.

\section{References}

1 Penner DW. Cost-effectiveness of the autopsy in maintaining and improving the standard of patient care. Am J Clin Pathol 1978;69:250-2.

2 Yesner R. Medical center autopsy costs. Am J Clin Pathol 1978;69:242-4.

3 Titus JL. Heart and vascular system. In: Ludwig J, ed. Current methods of autopsy practice. London: WB Saunders Co, 1972:61-5.

4 Galbraith S. The "no lose" philosophy in medicine. J Med Ethics 1978;4:61-3 